\title{
粘度差を利用した流出油回収の 現地実験 \\ FIELD EXPERIMENT OF RECOVERY FOR SPILLED OIL BY APPLYING WITH DIFFERENT VISCOSITY
}

\author{
高橋伸次郎 ${ }^{1}$ 、吉田稔 ${ }^{1} 、 大$ 大塚夏彦 ${ }^{2}$ 、宇佐美宣拓 ${ }^{3}$ 、荻原浩二 ${ }^{3}$ 、佐伯浩 ${ }^{4}$ \\ Shinjiro TAKAHASHI, Minoru YOSHIDA, Natsuhiko OTSUKA, \\ Norihiro USAMI, Kouji OGIWARA, Hiroshi SAEKI \\ ${ }^{1}$ 正会員 (株西村組（广⿳094-0012 北海道紋別市新港町 2丁目） \\ ${ }^{2}$ 正会員 北日本港湾コンサルタント(侏（テ003-0029 札幌市白石区平和通 2 丁目北 11-18） \\ 3 学生会員 北海道大学大学院工学研究科（T060-8628 札幌市北区北 13 条西 8 丁目） \\ ${ }^{4}$ フェロー会員 工博 北海道大学大学院工学研究科（テ060-8628 札幌市北区北 13 条西 8 丁目）
}

\begin{abstract}
There are currently several offshore oil and natural gas drilling projects being carried out in the Sea of Okhotsk. Therefore there has been increased the possibility of the ocean pollution of the coastal areas of Hokkaido on both the Japan Sea and Okhotsk Sea sides. Oil spilled from the oil tanker Nakhodka was recovered using buckets lowered from grab dredgers and self-propelled grab barges. This method of oil recovery was effective, but one problem was the large volume of sea water collected in buckets together with the oil. To resolve this problem, the authors developed a new type bucket with many holes in the bottom. The principle of the recovery method is to utilize difference in viscosity. This paper reports the recovery method for spilled oil by using newly developed buckets.
\end{abstract}

Key Words : Crude Oil, Oil Spill, Recovery Method, Bucket

\section{1. はじめに}

ナホトカ号の流出重油の回収にグラブ船、ガット 船が活躍したことは良く知られている(2)。しかし、 流出油と海水を混合した状態で回収したため、陸上 への輸送回数が増え、回収油一時貯蔵用ピットの容 量の増大が余儀なくされ、その後の産業廃棄物とし ての処理にも高額の費用がかかった。この問題に対 し、著者等はこれまでにガット船・グラブ船による バケットを用いた海上回収を対象に、流出油のみを 回収する方法について研究を行ってきた。

昨年末に高粘度対応型流出油回収船が北海道に配 置が決定されたが、これらが対象としている動粘度 は $10^{6} \mathrm{~mm}^{2} / \mathrm{s}$ 以上のムース状に変化した原油・重油 である。著者等は原油流出後 1 日経過した時の $10^{3} \mathrm{~mm}^{2} / \mathrm{s}$ 程度の動粘度ものから幅広く対応できる 回收法を検討した。バケットの実用性が検証される 事により、回収用のバケットを北海道のオホーツク
海沿岸に位置する港湾等に配置することになれば、 サハリン Iプロジェクト等における原油輸送に伴い 発生する可能性がある流出事故時には近隣する港か ら起重機船・ガット船の応援を得て、迅速な対応が 可能となる。また、バケットは陸上運搬が簡易なた め、配置する個数も少数化出来る。本研究は、著者 等が開発した粘度差を利用した流出油回収方法を大 規模な実験を行ってその有効性を確認したものであ る。

\section{2. 実験準備}

（1）実験ヤードの用意

実験ヤードの準備に際しては、紋別港第 3 埠頭地区 にて紋別市、海上保安部の協力を得て行った。 回収水域は紋別港第 3 埠頭地区にて建設中の埋立地 内に縌 $15 \mathrm{~m}$ 、横 $15 \mathrm{~m}$ 、深さ $3 \mathrm{~m}$ の形状に掘削し、 


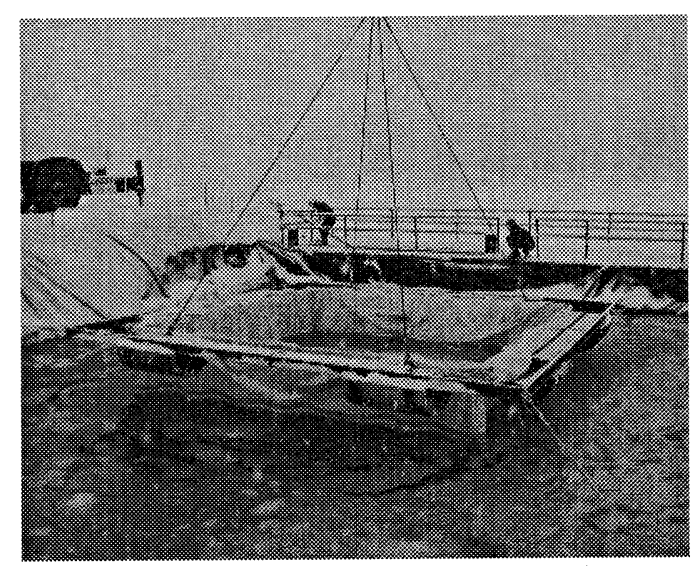

写-1. 二重オイルフェンスの設置

その内壁をビニールシートで覆った後、海水を入れ た。更に、その実験池内に $5 \mathrm{~m} \times 5 \mathrm{~m}$ のオイルフェ ンスを張り、二重に油の漏出防止を行った（写-1）。 この実験池の中で油を投入しラフタークレーン （45t）を用いて回収実験を行った。陸上にはバケ ットで回収した油を収集するため、回収箱を用意し た。これは起重機船による浚渫作業の様に、引き上 げた土砂をバージに積み込む状態を想定している。

（2）回収バケットの作製

ガット船及びクレーン船でバケットにより海水を引 き上げ、それをバージ船に投入するには、約 30 秒 で完了することが過去の研究において得られている。 そのため、バケット内の海水と油を分離するには約 15 秒から 20 秒の間に排水が完了し、引き上げてか ら 30 秒以上後に油が出始める事が望ましい。その ため、室内実験（バケットを利用した流出油の回収 に関する基礎的研究) で得られた結果より、図-1に 示す様なバケットを製作した。このバケットは縦 $153 \mathrm{~cm}$ 、横 $153 \mathrm{~cm}$ で容量 $2.66 \mathrm{~m}^{3}$ を有する。また、 このバケットの底は縦 $90 \mathrm{~cm}$ 、横 $90 \mathrm{~cm}$ 、の両開き の扉状の底版がついており、底版は開閉が可能であ る。 $2.4 \times 10^{4} \mathrm{~mm}^{2} / \mathrm{s}$ の動粘度を対象として、残った 油が孔から出るまでに約 10 秒となるよう孔の直径 と孔の長さ（底版の厚さ）が決定した。上述した様 に室内実験の結果から、底版には厚さ $4 \mathrm{~cm}$ で直径 $5 \mathrm{~mm}$ の孔が約 2000 個空けられている（写-2）。室 内実験の結果によれば底版が開放される時には回収 バケット内の海水は孔から落下し、回収した流出油 のみがバケット内に残っていることになる。尚、底 版の開閉にはクレーンのみで操作できるよう 2 種類 のワイヤーを用いて行う方が実際の作業条件となる のだが、実験の簡略化のためレバーブロックを使用 した。

\section{3. 実験方法}

この実験は次の項目の順に行った。

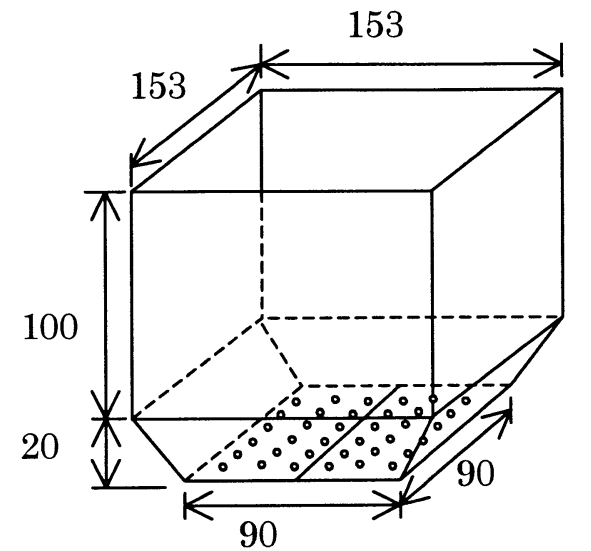

図ー1 作成した回収パケット unit: $\mathrm{cm}$

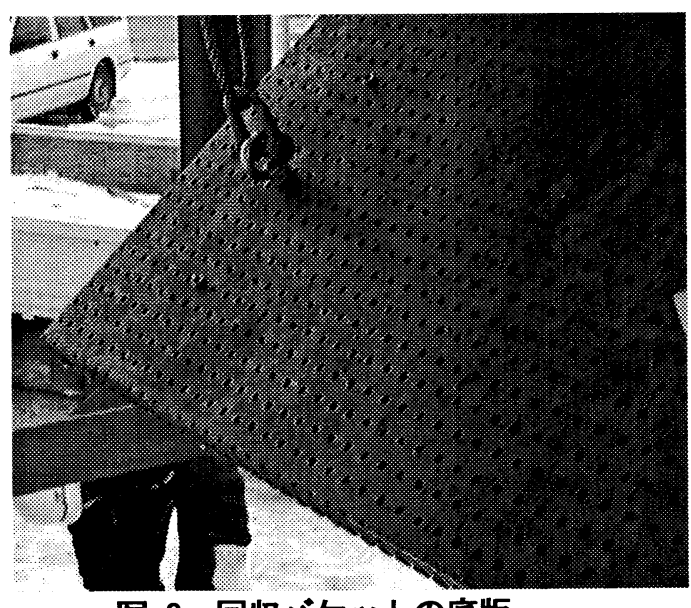

写-2. 回収パケットの底版

（1）排水時間の測定

海水のみの状態でバケットを引き上げ、海水が抜け る時間と流出速度等の実験を行い、理論の妥当性の 確認を行う。

(2) タイムラグの測定

バケットに海水を入れ、その表面に所定の量のギア オイルを入れ、バケットを引き上げ、海水が抜けた 後、ギアオイルが孔から出てくるまでの時間と油の 流量を測定する。これには粘度の異なる 3 種類の油 について実験を行い、粘性流体として扱った理論の 妥当性の検証を行う。

（3）回収時の分離状況

実験池内に油を投入し、それをバケットにより汲み 上げ、水を排出し、残った油のみを回収箱に入れる。 この時の油の回収量を測定する。これを複数回繰り 返して行い、実際の回収を再現する。

この時の海水の塩分量は $31.3 \%$ 、比重は 1.025 、ま た、実験には ISO 粘性グレード 460 (以下 ISO460)、 ISO 粘性グレード 460 と ISO 粘性グレード 1000 のギアオイルを 5:1 の割合で配合したもの（以下 460+1000（5:1））、SAE 粘性グレード 90 (以下 SAE90）の 3 種類のギアオイルを代替材料として 


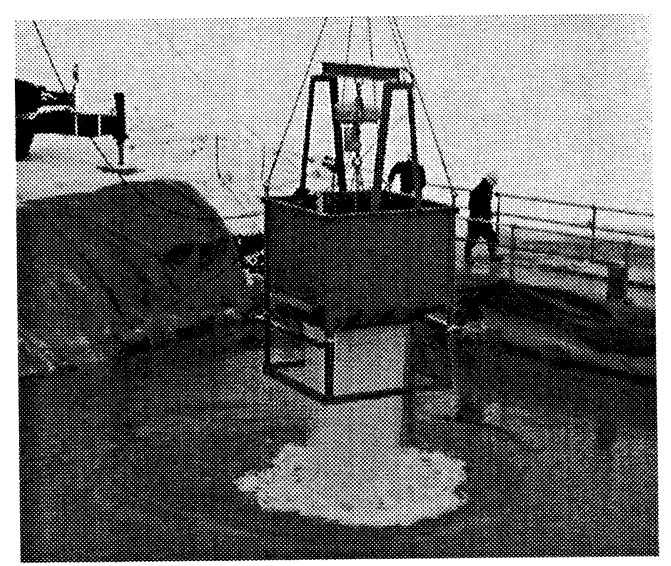

写-3. バケットからの排水

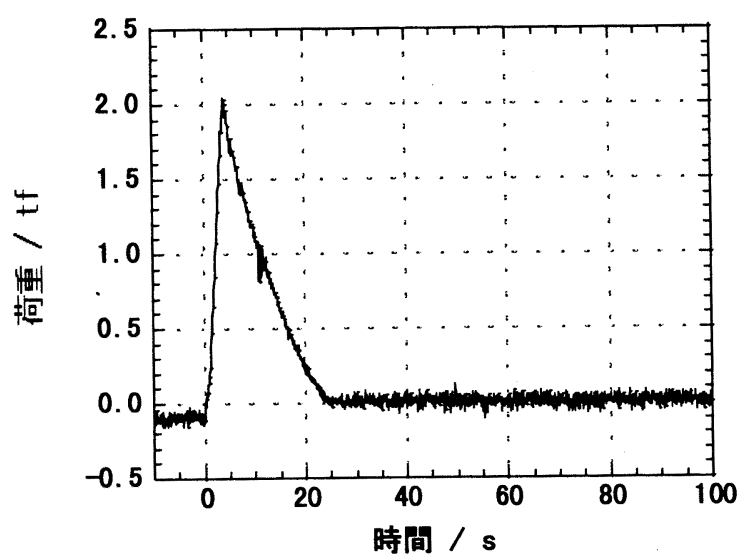

図-2. 海水排出量の経時変化

用いた。また、実験中は気温、海水温度、油温、そ れに油の粘度の測定を常時行った。また、回収バケ ットはロードセルを介してクレーンで吊られている。 この荷重変化から、海水、回収油の流出量等を測し た。

\section{4. 実験結果}

\section{1 排水時間}

排水時間の計算はオリフィス計算により行った。バ ケットの形状が下部において狭められているため、 上部の等断面と変断面に分けて計算した。この結果、 海水を底版から $87 \mathrm{~cm}$ の位置まで入れた条件で上部 で 13.7 秒、下部で 6.9 秒となり、合わせて 20.6 秒 となる。油を投入する前に海水のみを入れ、その排 水時間を測定した (図-2)。その結果、理論と十分 に一致した。油を海面に浮かした状態でもバケット 上昇させ、漏油が始まるまで空中に放置してから害 験池に戻し、繰り返し測定した。これは底版部に油 を付着させ、油回収作業を繰り返し行った条件とな るよう考慮したためである。この結果、海水は約 20 秒で排出完了した (写-3)。また、油の層厚を $2 \mathrm{~cm}$ から $6 \mathrm{~cm}$ まで変化させても、粘度の異なる油を

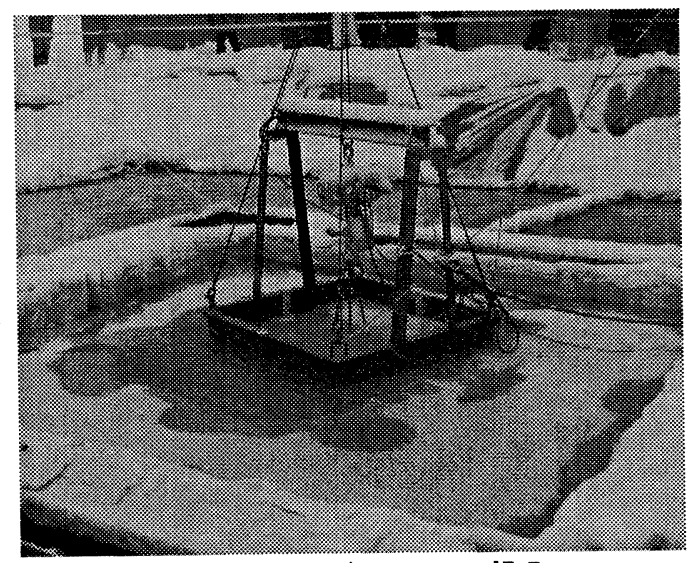

写-4. 回収パケットの投入

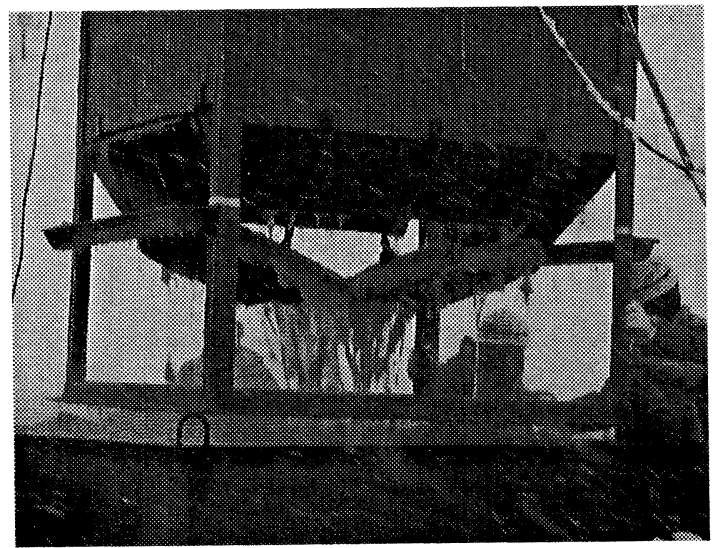

写-5. 油と海水の分離

用いても排水時間には影響は無かった。

\section{2 タイムラグ}

油の粘度の増加に伴い、底版の孔から油が流出した ときまでの時間（タイムラグ）は増加する（表-1）。 計算により算出したものと比較してみると、誤差の 範囲内で一致している。今回、孔を決定するのに対 象とした動粘度は $1.1 \times 10^{4} \mathrm{~mm}^{2} / \mathrm{s}$ 、油層厚 $30 \mathrm{~mm}$ である。SAE90 の様な動粘度が低い場合 $\left(5.5 \times 10^{3}\right.$ $\left.\mathrm{mm}^{2} / \mathrm{s} 、 \mathrm{t}=26 \mathrm{~mm}\right)$ にはタイムラグは 10 秒程に漏 油が早まっている。しかし、旋回時間は約 30 秒程 度であるため、その流出量は殆ど影響ない。また 2.2 $\times 10^{4} \mathrm{~mm}^{2} / \mathrm{s}$ ではタイムラグは約 40 秒となり、旋 回時間内には漏油しないため、回収率は低下しない。 従って、実験值と理論值がほぼ一致していることか ら、この様な高粘度であっても八ーゲン・ポワジュ 一ユの理論は適応可能であると言える。

底版を閉めたままロードセルの荷重から読み取った 落下流量を時間に対し一次の関数として近似したと ころ、 $5.1 \times 10^{3} \mathrm{~mm}^{2} / \mathrm{s}$ においては $0.114 \mathrm{~L} / \mathrm{s}$ である。 回収量 $60 \mathrm{~L}$ に対して油が落下し始めてから 10 秒経 過したとしても僅かに $1.14 \mathrm{~L}$ 漏れる程度である。計 算から得られた結果では $0.157 \mathrm{~L} / \mathrm{s}$ であった。 


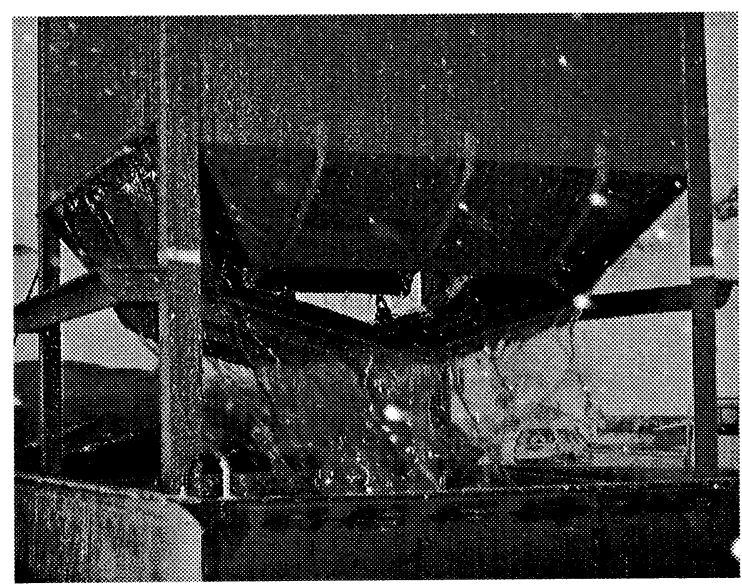

写-6. 油のみ回収

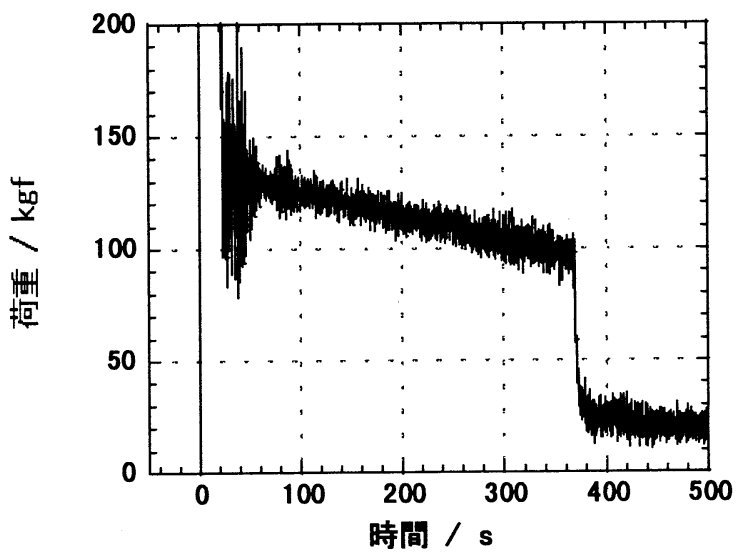

図-3. 回収時の経時変化

また、 $1.0 \times 10^{4} \mathrm{~mm}^{2} / \mathrm{s}$ の場合にも理論値 $0.128 \mathrm{~L} / \mathrm{s}$ に対し実験值 $0.118 \mathrm{~L} / \mathrm{s}$ となった。排水時間が 20 秒 程度であるため、漏油まで 10 秒以上であれば、こ の漏油量は回収において無いこととなる。また、回 収に要する時間が 1 分近くまでかかった場合にも数 パーセントしかロスしない。

\section{3 回収量}

壁面に付着する厚さは高粘度の時の方が大きいが、 数回回収を繰り返すと回収率は一定となった。この ため、壁面に付着する量は粘度により一定であり、 回収率には影響しない。実際に $1.6 \times 10^{4} \mathrm{~mm}^{2} / \mathrm{s}$ 、 $\mathrm{t}=20 \mathrm{~mm}$ では 3 回目にして投入量 $47 \mathrm{~L}$ に対し $49.5 \mathrm{~L}$ 回収された。これは外壁に付着した油が落下してい るためである。そのため、回収量はバケット内に回 収された油よりも多くなっている。 $1.0 \times 10^{4} \mathrm{~mm}^{2} / \mathrm{s}$ の場合にも投入量 $135 \mathrm{~L}$ に対し回収量 $132 \mathrm{~L}$ 之高回 収率を示した。25 m²に投入した油は回収回数の 増加に伴い油層厚が低下するため、回収量は低下寸 るが、実際の回収作業においてはオイルフェンスを 曳船もしくは起重機船のウインチを利用して狭くし、 油層厚を増加させればよい。

\begin{tabular}{ccccc}
\hline 動粘度 & \multicolumn{2}{c}{ 油層厚 } & 排水時間 & \multicolumn{2}{c}{ タイムラグ $(\mathrm{sec})$} \\
$\nu\left(\mathrm{mm}^{2} / \mathrm{s}\right)$ & $\mathrm{t}(\mathrm{mm})$ & $(\mathrm{sec})$ & 実測值 & 計算值 \\
\hline $5.1 \times 10^{3}$ & 26 & 24.0 & 9.0 & 10.1 \\
$1.03 \times 10^{4}$ & 26 & 20.5 & 20.3 & 20.5 \\
$1.47 \times 10^{4}$ & 20 & 23.0 & 31.8 & 33.6 \\
$1.62 \times 10^{4}$ & 20 & 25.0 & 35.9 & 37.0 \\
$1.00 \times 10^{4}$ & 57 & 22.1 & 15.0 & 12.4 \\
$2.18 \times 10^{4}$ & 52 & 26.3 & 30.0 & 27.7 \\
\hline
\end{tabular}

\section{表-1. 動粘度とタイムラグの関係}
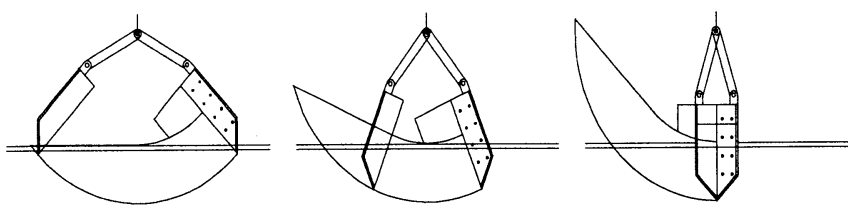

図-4 改良型グラブバケットの模式図

各粘度を通して、全体の回収量は回収回数 40 回に 対し、約 8001 となり、1.51 程度の海水しか含まれ ていなかった。また、高粘度の場合には 0.5〜2mm 厚で油が付着するが、繰り返し作業を行ってもその 厚さに変化はなく、また孔の目詰まりも全く発生な かった。

今回使用した回収装置は底面の面積が狭められてい るため、バケットの上方部と下方部が同じ寸法の方 が回収率は向上する。そこで、グラブバケットを改 良した形状を考案中である（図-4）。これは回収時 の水面での面積はバケット幅の約 2 倍程度になるた め、回収率も高まる。通常の形式でバケットを閉じ たときにはその隙間に流れが発生し、漏れてしまう ため、流出防止にウイングを設けた。底版部には今 回の実験で用いられた孔を開け、油と海水を分離出 来るようになっている。

\section{5. 結論}

今回用いた油の粘度から、回収バケット底版の孔の 直径を $5 \mathrm{~mm}$ 、長さ (板厚) を $40 \mathrm{~mm}$ とし、海水の 排出時間を 20 秒とするため、孔の数を 2025 とし てバケット底版を設計したが、海水の排水時間はほ ぼ理論と一致した。

海面に油を浮かした状態での実験では、バケット上 昇後約 20 秒で海水が完全に抜け、そのあと時間を 置いて回収油の一部が孔からゆっくり排出してきた。 水が完全に抜けてから、油が孔から出てくる時間は、 油を粘性流体としてハーゲン・ポワジューユ流れを 仮定した理論から計算される値とほぼ一致した。ま た、排出する流量も初期を除いて理論と一致した。 初期の理論と合わない点は、孔から出た油が底板裏 
面に水滴状に付着するためであった。また、ハーゲ ン・ポワジューユの理論は ISO グレード 460 程度 の高粘性流体にも充分適用できることが再確認され た。

バケット内壁部には、高粘性油の場合、0.5 $2 \mathrm{~mm}$ 厚で油が付着するが、繰り返し作業を行ってもその 厚さに変化はなく、また孔の目詰まりも全く発生し なかった。

約 40 回の回収実験後、回収箱には約 8001 の油が回 収されたが、海水は $0.2 \%$ 以下であった。この回収 方法で流出油と海水が効率良く分離されることが明 らかとなった。

油の層厚の違いにより、回収率の影響は差ほど無か った。

\section{参考文献}

1）高橋伸次郎、米田克幸、大島香織、大塚夏彦、 佐伯浩：流出した原油の回収に関する基礎的研究、 海洋開発論文集、第 15 巻、pp553-557、1999

2) proceedings of International Symposium on Marine 0il Spill Response, Editor: Seizo Motora et al. 1997, Tokyo 